\title{
Morphometric differentiation of mixed coat coloured cattle in Obudu Grass Plateau, South-South Nigeria.
}

\author{
Anya MI, Dauda A*, Ayuk AA, Okon BI, Okpako OP \\ Department of Animal Science, University of Calabar, Nigeria
}

\begin{abstract}
Obudu Grass Plateau for phenotypic traits measurement. The phenotypic traits measured were Body Weight (BW), Body Length (BL), Height Withers (HW), Head Length (HDL), Head Width (HDW), Ear Length (EL), Horn Length (HL), Tail Length (TL), Dewlap width (DW), Scrotal Circumference (SC), Udder Circumference (UC), Number of Teats (NOT), F Fore Length (FLG), Hind Length (HLG), Cannon Circumference (CCF), Horn circumference (HNC), Cannon Length (CL), Rump Width (RW), Rump Length (RL), Heart Girth (HG). The data were analysed using SPSS. The fixed effects of age and lots on phenotypic traits were tested using linear model. The result revealed age and lots have significant $(\mathrm{P}<0.05)$ effect on phenotypic traits of cattle in Obudu cattle ranch. The result of correlation among phenotypic traits showed body weight has positive correlation rp $(+)$ with all the phenotypic traits, while cannon length had negative rp (-) correlation with all the phenotypic traits except scrotal circumference (SC), udder circumference (UC) and body weight (BW). The positive correlation among phenotypic traits could be used for improvement because improvement in one will lead to improvement in others. The study will be useful in planning for selection and breeding programmes of cattle.
\end{abstract}

Keywords: Phenotypic, Traits, Cattle, Correlation.

Accepted on November 30, 2018

\section{Introduction}

The characterization of local genetic resources depends on the knowledge of the variation of morphological traits, which have played a very fundamental role in classification of livestock based on size and shape [1]. Size and conformation are important characteristics in meat animals especially ruminants. Traditionally, animals are usually assessed visually, which is a subjective method of judgment [2]. The need for characterization of livestock breeds is a cornerstone for understanding their uniqueness and ability to thrive under various agro climates [3]. The "phenotype" of an animal is the resultant of the genetics and its peerless blending with the environment where it thrives. The phenotype is further subjected to the social and aesthetic relationships of the owners and the aim for which they were developed [4]. Phenotypic characterization is all the more important for livestock that can thrive well under changing climatic conditions and in unfavourable environments [5]. "Phenotypic characterization of livestock generally refers to the process of identifying distinct breed populations and describing their external and production characteristics within a given production environment", [6]. Thus, it becomes necessary to phenotypically characterize the livestock before applying advanced characterization techniques [6]. Physical body measurements are of very common use in husbandry and phenotypic characterization of cattle. Common physical body measurements used in phenotypic characterization of cattle include body weight, heart girth, withers height, body length, ear length, horn length, muzzle circumference, hock circumference and tail length among several others. However, based on relatively large numbers of loci, body measurements have a continuous expression and may be directly correlated to body size and associated production traits [7]. This paper was designed to investigate the effect of age and lots on phenotypic traits of multiple crossed cattle as well as correlation among these traits.

\section{Materials and Methods}

\section{Study area}

The study area is the Obudu Grass Plateau located in the Obanliku Local Government Area of Cross River State, SouthSouth Nigeria. It lies between longitude $90^{\circ} 22^{\prime} 00^{\prime \prime}$ and $90^{\circ}$ $22^{\prime} 45^{\prime \prime} \mathrm{E}$, and latitude $60^{\circ} 21^{\prime} 30^{\prime \prime}$ and $60^{\circ} 22^{\prime} 30^{\prime \prime} \mathrm{N}$, with an approximate area of $104 \mathrm{sqm}^{2}$, and a height of about 1576 $\mathrm{m}$ above sea level [8]. Obudu Plateau is bounded in the north by Benue State, northeast by the Republic of Cameroon, to the southeast by Boki Local Government Area in Cross River State of Nigeria. The area is situated within the tropics but it has a climate that is likened to temperate region with mean daily temperatures range between $15^{\circ} \mathrm{C}$ and $22^{\circ} \mathrm{C}$. It has a mean annual rainfall of about $4300 \mathrm{~mm}$ with highest rainfall of about $76.2 \mathrm{~cm}$ usually recorded in August while the lowest of $0.76 \mathrm{~cm}$ is usually recorded in December [9]. The Obudu Plateau is part of the Precambrian Basement Complex of Nigeria [8]. 


\section{Management system of the experimental animals}

The animals were managed under extensive system with little or no provision of shelter in the day and night. The animals are kept in lots in the night and the lots are fence with stick or barb wires. The calves were separated from the cows in the night. They grazed during the day time on natural pasture. Adequate health care was in existent while uncontrolled breeding was also practice. Other management practice such as hand pick of ticks; castration and mineral salt were given as supplement.

\section{Phenotypic traits}

A total of 333 (153 females and 150 males) were randomly sampled from the population of cattle in Obudu for phenotypic traits measurement. The phenotypic traits measured were Body Weight (BW), Body Length (BL), Height Withers (HW), Head Length (HDL), Head Width (HDW), Ear Length (EL), Horn Length (HL), Tail Length (TL), Dewlap width (DW), Scrotal Circumference (SC), Udder Circumference (UC), Number of Teats (NOT), F Fore Length (FLG), Hind Length (HLG), Cannon Circumference (CCF), Horn circumference (HNC), Cannon Length (CL), Rump Width (RW), Rump Length (RL), Heart Girth (HG). The body weight was measured with glasfiber band with model number WJ515. Height-at-wither was measured with two meter rule while other phenotypic traits were measured with graduated tape. The measurements were done in the morning before the animals were released for grazing. All the measurements were carried out by same person in order to avoid inter individual variations.

\section{Statistical analysis}

The data set was analysed using SPSS. The fixed effects of age and lots on phenotypic traits were tested using linear model given as follows:

$Y i j k=\mu+A i+L j+e i j k$

Where: Yijk=Individual observation of each body traits.

$\mu=$ Overall mean.

$\mathrm{Ai}=$ Fixed effect of $i^{\text {th }}$ age.

$\mathrm{S} j=$ Fixed effect of $\mathrm{j}^{\text {th }}$ lot.

eijw=Random residual error asocial with record of each animal.

Data set were also subjected to Pearson correlation analysis.

\section{Results and Discussion}

The results of effect of age on phenotypic traits are presented in Table 1 . All the phenotypic traits showed significance $(p<0.05)$ difference with change in age except dewlap width, horn circumference, head length, ear length, fore leg, hind leg and rump length. The phenotypic traits change with increase in age from 0-3 years to 10-12 years beside, phenotypic traits such as body weight, head length, chest circumference, rump length, head width, dewlap width, udder circumference, fore leg and hind leg decrease with age above 12 years. This may be due to old age or the animal is at the diminishing point. Although other parameters that showed statistical the same also follow the same trend which increases in age. These findings agreed to the result of Adejoro and Salako [10] who reported that the general positive influence of age of the animals on body size and weight is not surprising since the size and shape of the animals is expected to increase with increasing age of the animal. The result from this study also concurred with the report of Dauda et al. [11] who opined that Age and sex have great influence on body traits of animals. The author further stated that increase in age leads to increase in body trait; this could be term as growth. At 10-12 year may be ideal age for selection in cattle because it is the age that exposed most or all the phenotypic traits. Since Body size and shape measured objectively could improve selection for growth by enabling the breeder to recognize early maturing and late maturing animals of different sizes. Measurement of various body conformations are of value in judging quantitative characteristics of meat animals and are also helpful in developing suitable selection criteria $[12,13]$.

The results of effect of lots on phenotypic traits are presented in Table 2. The results revealed that animals in lots 8 are superior in body weight, body length, height-at-wither, head length, head width, ear length, horn length, horn circumference, tail length, dewlap width, heart girth, rump length, rump width, scrotal circumference, hind leg, fore leg except udder circumference was superior in lot 9 and cannon length in lot 1 . The superiority of animals in lot 8 over other lots in the study area could be due to differences in breeds and good management practices such as hand pick of ticks, castration and deworming. Besides, the body length in this study ranges from $(80.00-124.00) \mathrm{cm}$ which is lower than the findings of Yakubu et al. [1] who reported value of $175.29 \mathrm{~cm}$ and $179.02 \mathrm{~cm}$ for Bunaji and Sokoto Gudali cattle respectively. Height-at-wither in this study revealed (100.40-s135.77) cm is higher than $111.84 \mathrm{~cm}$ and $127.50 \mathrm{~cm}$ for Bunaji and Sokoto Gudali respectively as reported by Yakubu et al. [1]. The estimates obtained for height at withers of adult cattle in this study is also higher than those of the Nandi (110-122) cm, Mongalla (100-110) cm [14], and Mexican Criollo Chinampo (101-117) cm [15] but lower than Sudan Baggara (115.9-148.80) cm [16]. The heart girth values in this study ranges from (122.76-170.41) $\mathrm{cm}$ are, however, higher than the range of $122-127 \mathrm{~cm}$ reported for North Bengal Grey cattle in Bangladesh [16]. The tail length, rump length and rump width in this study ranges from $(75.80-101.87) \mathrm{cm}$ and (25.60-40.36) $\mathrm{cm}$ respectively. This agreed with the value of tail length $76.81 \mathrm{~cm}$ and $84.27 \mathrm{~cm}$ and rump length of $39.06 \mathrm{~cm}$ and $42.17 \mathrm{~cm}$ for Bunaji and Sokoto Gudali respectively as reported by Yakubu et al. [1]. The author further opined that Comparative measurements of morphometric traits can provide evidence of breed relationships and size. The variations in phenotypic traits on lots may be connected with individual's potentials and true to type. Since morphometric measurements have been used to evaluate the characteristics of various breeds of animals and could provide useful information on the suitability of animals for selection $[17,18]$. The results of correlation among phenotypic traits are presented in Table 3. The correlation among phenotypic traits, body weight positively correlated (rp) with all the phenotypic. The rp are highly significant $(\mathrm{p}<0.01)$ and ranges from low 0.031 to high 0.943 . The positive correlations that exist between body weight and all the phenotypic traits could mean that they are controlled by same gene (pleiotropic), similarly it is an indication that any of those phenotypic trait could serve as a predictor of body weight [19]. This may also be that improvement in one trait may also lead to improvement in 
Table 1. Effect of age on phenotypic traits.

\begin{tabular}{|c|c|c|c|c|c|c|}
\hline Parameters & $0-3$ years & 4-6 years & 7-9 years & $10-12$ years & $>12$ year & SEM \\
\hline Body weight & $272.88^{c}$ & $413.56^{\mathrm{ab}}$ & $456.33^{\mathrm{a}}$ & $424.00^{\mathrm{ab}}$ & $358.00^{\mathrm{ab}}$ & 9.161 \\
\hline Body length & $94.89^{b}$ & $110.56^{\mathrm{ab}}$ & $108.83^{\mathrm{ab}}$ & $111.75^{\mathrm{ab}}$ & $121.00^{\mathrm{a}}$ & 1.289 \\
\hline Height-at-wither & $116.80^{\circ}$ & $130.30^{\mathrm{ab}}$ & $129.50^{\mathrm{b}}$ & $131.92^{\mathrm{a}}$ & $138.00^{\mathrm{a}}$ & 1.188 \\
\hline Head length & 42.29 & 48.19 & 50.17 & 49.67 & 48.00 & 777 \\
\hline Head width & $18.79^{\mathrm{b}}$ & $20.38^{\mathrm{ab}}$ & $19.33^{\mathrm{ab}}$ & $19.38^{\mathrm{ab}}$ & $19.00^{\mathrm{ab}}$ & 436 \\
\hline Ear length & 20.51 & 21.20 & 22.83 & 22.33 & 21.00 & 267 \\
\hline Horn length & $21.65^{\circ}$ & $38.77^{\mathrm{b}}$ & $47.67^{\mathrm{ab}}$ & $54.58^{\mathrm{a}}$ & $55.00^{\mathrm{a}}$ & 1.262 \\
\hline Horn circumference & 17.41 & 18.89 & 18.83 & 18.75 & 18.00 & 454 \\
\hline Tail length & $86.16^{\mathrm{b}}$ & $99.70^{\mathrm{ab}}$ & $101.50^{\mathrm{ab}}$ & $104.00^{\mathrm{ab}}$ & $112.00^{\mathrm{a}}$ & 1484 \\
\hline Dewlap width & 15.07 & 17.86 & 18.33 & 18.50 & 14.00 & 640 \\
\hline Udder circumference & $51.50^{\mathrm{ab}}$ & $48.41^{\mathrm{ab}}$ & $60.00^{\mathrm{a}}$ & $54.50^{\mathrm{ab}}$ & $43.00^{b}$ & 1.533 \\
\hline Number of teat & $4.03^{\mathrm{b}}$ & $4.00^{\mathrm{b}}$ & $4.00^{\mathrm{b}}$ & $4.00^{\mathrm{b}}$ & $6.00^{\mathrm{a}}$ & 034 \\
\hline Fore limb & 81.51 & 90.63 & 88.50 & 89.00 & 79.00 & 903 \\
\hline Hind limb & 98.22 & 105.34 & 104.50 & 104.33 & 100.00 & 1.042 \\
\hline Cannon circumference & $18.04^{b}$ & $21.88^{b}$ & $22.00^{\mathrm{b}}$ & $23.47^{\mathrm{b}}$ & $26.00^{\mathrm{b}}$ & 2.002 \\
\hline Cannon length & $66.37^{\mathrm{a}}$ & $68.41^{a}$ & $65.33^{\mathrm{a}}$ & $68.17^{\mathrm{a}}$ & $63.00^{\mathrm{a}}$ & 1700 \\
\hline Rump width & $31.81^{b}$ & $40.00^{a}$ & $42.33^{\mathrm{a}}$ & $41.17^{\mathrm{a}}$ & $42.00^{\mathrm{a}}$ & 1240 \\
\hline Rump length & 19.30 & 19.97 & 20.17 & 20.67 & 17.00 & 856 \\
\hline Heart girth & $144.34^{\mathrm{b}}$ & $170.77^{\mathrm{a}}$ & $175.80^{\mathrm{a}}$ & $166.15^{\mathrm{a}}$ & $162.20^{\mathrm{a}}$ & 1.686 \\
\hline
\end{tabular}

Table 2. Effect of lots on phenotypic traits.

\begin{tabular}{|c|c|c|c|c|c|c|c|c|c|c|}
\hline \multicolumn{11}{|c|}{ Lots } \\
\hline Parameters & 1 & 2 & 3 & 4 & 5 & 6 & 7 & 8 & 9 & SEM \\
\hline Body weight & $289.91^{b c}$ & $313.21^{\mathrm{bc}}$ & $363.75^{\mathrm{ab}}$ & $335.58^{\mathrm{bc}}$ & $170.20^{d}$ & $276.40^{\mathrm{bc}}$ & $298.55^{\mathrm{bc}}$ & $440.91^{a}$ & $266.25^{c}$ & 9.286 \\
\hline Body length & $87.95^{\text {bc }}$ & $93.52^{\mathrm{cd}}$ & $105.93^{\mathrm{bc}}$ & $102.03^{b c}$ & $80.00^{e}$ & $102.40^{\mathrm{bc}}$ & $107.27^{\mathrm{b}}$ & $124.00^{\mathrm{a}}$ & $102.06^{\mathrm{bc}}$ & 1.295 \\
\hline Height at withers & $115.94^{b}$ & $119.55^{b}$ & $123.98^{\mathrm{b}}$ & $122.29^{b}$ & $100.40^{c}$ & $117.72^{\mathrm{b}}$ & $120.45^{b}$ & $135.77^{\mathrm{a}}$ & $127.13^{\mathrm{ab}}$ & 1.200 \\
\hline Head length & 43.52 & $44.86^{3}$ & $44.14^{5}$ & $45.79^{2}$ & $39.00^{8}$ & $44.20^{4}$ & $41.45^{7}$ & $47.73^{1}$ & $43.25^{6}$ & 0.777 \\
\hline Head width & $19.87 a b$ & $19.95 a b$ & $18.21^{\mathrm{bc}}$ & $18.58^{\mathrm{bc}}$ & $15.40^{\circ}$ & $18.00^{\mathrm{bc}}$ & $17.09^{\mathrm{bc}}$ & $22.45^{\mathrm{a}}$ & $16.38^{\mathrm{bc}}$ & 0.368 \\
\hline Ear length & 19.59ab & $20.67 a b$ & $21.18^{a}$ & $21.95^{\mathrm{a}}$ & $18.00^{\circ}$ & 20.63 ab & $19.91^{\mathrm{ab}}$ & $22.23^{a}$ & $20.03 a b$ & 0.271 \\
\hline Horn length & $26.50^{\mathrm{b}}$ & $27.09^{b}$ & $34.82^{b}$ & $27.17^{b}$ & $13.20^{c}$ & $22.45^{c}$ & $23.41^{b c}$ & $46.95^{a}$ & $24.88^{a b}$ & 1.272 \\
\hline Tail length & $87.83^{\mathrm{abcd}}$ & $87.59^{\mathrm{abcd}}$ & $95.21^{\mathrm{abc}}$ & $96.45^{\mathrm{ab}}$ & $75.80^{d}$ & $88.20^{\mathrm{abcd}}$ & $78.91^{\mathrm{dd}}$ & $101.87^{\mathrm{a}}$ & $84.50^{\text {bcd }}$ & 1.552 \\
\hline Dewlap width & $12.22^{\mathrm{ab}}$ & $17.03^{\mathrm{a}}$ & $18.54^{\text {a }}$ & $17.47^{\mathrm{a}}$ & $9.70^{b}$ & $14.50^{\mathrm{ab}}$ & $14.36^{\mathrm{ab}}$ & $19.30^{\mathrm{a}}$ & $14.39^{\mathrm{ab}}$ & 0.652 \\
\hline Scrotal & 26.00 & 28.55 & 25.00 & 28.25 & 16.00 & 22.58 & 24.33 & 53.00 & 19.33 & 1.795 \\
\hline Udder Circumference & 50.60 & 58.60 & 51.00 & 45.11 & -- & -- & 54.00 & 50.14 & 61.00 & 1.555 \\
\hline number teat & $4.00^{\mathrm{b}}$ & $4.00^{\mathrm{b}}$ & $4.00^{\mathrm{b}}$ & $4.08^{b}$ & $4.50^{\mathrm{a}}$ & $4.00^{b}$ & $4.00^{b}$ & $4.00^{b}$ & $4.00^{b}$ & 0.028 \\
\hline Fore limb & 86.70 & 85.69 & 86.43 & 82.36 & 75.40 & 82.40 & 81.18 & 88.64 & 80.00 & 0.914 \\
\hline Hind limb & $94.93^{a}$ & $102.34^{\mathrm{a}}$ & $103.06 a$ & $97.68^{a}$ & $88.00^{\mathrm{b}}$ & $97.90^{\mathrm{a}}$ & $98.36^{a}$ & $108.36^{a}$ & $101.38^{a}$ & 1.061 \\
\hline Cannon circumference & $28.00^{\mathrm{bcd}}$ & $36.09^{\mathrm{abc}}$ & $49.00^{\mathrm{ab}}$ & $31.95^{\mathrm{bcd}}$ & $13.80^{d}$ & $21.90^{\mathrm{cd}}$ & $39.00^{\mathrm{abc}}$ & $55.55^{\mathrm{a}}$ & $23.50^{\text {cd }}$ & 2.039 \\
\hline Circumference horn & $19.50^{\mathrm{a}}$ & $17.59^{a}$ & $18.21^{\mathrm{a}}$ & $18.92^{\mathrm{a}}$ & $12.70^{c}$ & $18.00^{\mathrm{ab}}$ & $13.55^{\mathrm{bc}}$ & $20.41^{a}$ & $17.75^{\text {cd }}$ & 0.457 \\
\hline cannon length & $67.74^{\mathrm{a}}$ & $52.96 \mathrm{~b}$ & $37.34^{d}$ & $54.88^{\mathrm{a}}$ & $62.80^{a}$ & $62.80^{a}$ & $54.09^{a}$ & $36.64^{b}$ & $63.00^{a}$ & 1.786 \\
\hline Rump length & $31.65^{\mathrm{bc}}$ & $33.24^{\mathrm{ab}}$ & $37.57^{\mathrm{ab}}$ & $35.79^{a b}$ & $25.60 c$ & $32.90^{\mathrm{ab}}$ & $34.45^{\mathrm{ab}}$ & $40.36^{b}$ & $36.38^{\mathrm{ab}}$ & 0.584 \\
\hline Rump width & $20.13^{b}$ & $18.69^{b}$ & $19.14^{b}$ & $18.45^{b}$ & $16.00^{\mathrm{b}}$ & $16.90^{\mathrm{b}}$ & $18.91^{b}$ & $20.00^{b}$ & $31.93^{b}$ & 0.0074 \\
\hline Heart girth & $149.06^{b c}$ & $154.05^{\mathrm{abc}}$ & $161.47^{a b c}$ & $153.47^{a b c}$ & $122.76^{d}$ & $144.97^{d}$ & $148.98^{\mathrm{bc}}$ & $170.41^{\mathrm{a}}$ & $143.44^{c}$ & 1.71 \\
\hline
\end{tabular}

Table 3. Correlation among phenotypic traits.

\begin{tabular}{|c|c|c|c|c|c|c|c|c|c|c|c|c|c|c|c|c|c|c|}
\hline & BW & BL & HW & HL & Head W & EL & Horn L & TL & DL & sc & UC & Fore LL & HLL & C.CF & $\mathrm{HC}$ & CL & RW & RL \\
\hline \multicolumn{19}{|l|}{ BW } \\
\hline BL & $0.737^{\star *}$ & & & & & & & & & & & & & & & & & \\
\hline HW & $0.841^{* \star}$ & $0.758^{\star \star}$ & & & & & & & & & & & & & & & & \\
\hline HL & $0.504^{\star *}$ & $0.340^{*}$ & $0.462^{*}$ & & & & & & & & & & & & & & & \\
\hline Head W & $0.392^{*}$ & 0.286 & $0.414^{*}$ & $0.404^{\star \star}$ & & & & & & & & & & & & & & \\
\hline EL & $0.386^{*}$ & $0.312^{*}$ & $0.373^{*}$ & 0.123 & 0.182 & & & & & & & & & & & & & \\
\hline Horn L & $0.73^{\star *}$ & $0.606^{* *}$ & $0.680^{* *}$ & $0.408^{*}$ & $0.343^{*}$ & $0.372^{*}$ & & & & & & & & & & & & \\
\hline TL & $0.553^{* \star}$ & $0.498^{*}$ & $0.482^{*}$ & $0.348^{\star}$ & 0.235 & $0.319^{*}$ & $0.342^{*}$ & & & & & & & & & & & \\
\hline DL & $0.346^{*}$ & 0.295 & $0.373^{*}$ & 0.176 & 0.183 & 0.271 & 0.223 & 0.191 & & & & & & & & & & \\
\hline sc & $0.632^{\star \star}$ & $0.486^{*}$ & $0.574^{\star *}$ & $0.431^{*}$ & 0.202 & 0.158 & 0.144 & $0.391^{*}$ & $0.589^{* *}$ & & & & & & & & & \\
\hline UC & 0.031 & 0.026 & 0.090 & $0.311^{*}$ & 0.088 & 0.045 & 0.126 & -0.046 & 0.087 & & & & & & & & & \\
\hline Fore LL & $0.530^{* \star}$ & $0.358^{*}$ & $0.535^{\star *}$ & $0.306^{\star}$ & 0.297 & $0.173^{*}$ & $0.389^{*}$ & $0.389^{*}$ & 0.142 & $0.319^{*}$ & 0.137 & & & & & & & \\
\hline Hind LL & $0.535^{* *}$ & $0.457^{*}$ & $0.544^{* *}$ & $0.365^{\star}$ & 0.295 & $0.199^{*}$ & $0.405^{\star}$ & $0.405^{*}$ & $0.188^{*}$ & 0.212 & 0.264 & $0.465^{*}$ & & & & & & \\
\hline C.CF & $0.618^{\star \star}$ & $0.500^{* *}$ & $0.470^{*}$ & $0.413^{*}$ & 0.255 & 0.15 & $0.610^{* *}$ & $0.610^{\star *}$ & 0.16 & 0.241 & -0.075 & $0.363^{*}$ & 0.275 & & & & & \\
\hline $\mathrm{HC}$ & $0.663^{\text {** }}$ & $0.554^{\star *}$ & $0.666^{\star \star}$ & $0.643^{\star \star}$ & $0.625^{\star \star}$ & $0.360^{*}$ & $0.463^{*}$ & $0.463^{*}$ & 0.196 & $0.473^{*}$ & -0.094 & $0.577^{*}$ & $0.467^{\star}$ & $0.212^{\star \star}$ & & & & \\
\hline $\mathrm{CL}$ & $0.421^{*}$ & -0.41 & -0.275 & $-0.349^{*}$ & -0.125 & -0.124 & $-0.495^{*}$ & $-0.495^{\star}$ & -0.14 & 0.151 & 0.034 & -0.192 & -0.113 & $-0.919^{* *}$ & -0.088 & & & \\
\hline RW & $0.810^{* \star}$ & $0.763^{\star \star}$ & $0.773^{\star \star}$ & $0.504^{\star \star}$ & 0.225 & $0.301^{*}$ & $0.646^{* *}$ & $0.525^{* *}$ & 0.240 & $0.521^{* *}$ & $0.316^{*}$ & $0.429^{*}$ & $0.453^{*}$ & $0.553^{\star \star}$ & $0.577^{\star \star}$ & $-0.435^{\star \star}$ & & \\
\hline $\mathbf{R L}$ & 0.103 & 0.115 & 0.142 & 0.06 & 0.036 & -0.22 & 0.094 & 0.094 & 0.043 & 0.014 & 0.259 & 0.037 & 0.111 & 0.042 & 0.134 & 0.77 & 0.137 & \\
\hline HG & $0.943^{* *}$ & $0.723^{* *}$ & $0.815^{\star \star}$ & $0.505^{\star \star}$ & $0.402^{*}$ & $0.316^{*}$ & $0.676^{\star *}$ & $0.519^{* *}$ & $0.323^{*}$ & $0.589^{\star *}$ & 0.157 & $0.546^{\star *}$ & $0.653^{\star \star}$ & $0.612^{\star *}$ & $0.648^{* *}$ & $-0.418^{\star \star}$ & $0.816^{\star \star}$ & 0.117 \\
\hline
\end{tabular}

${ }^{* *}=$ Highly significant $(p<0.001) .^{*}=$ significant $(p<0.05) \mathrm{KEY}$ : BW=Body Weight, BL=Body Length, HW=Height Withers, HL=Head Length, HW=Head Width, EL=Ear Length, Horn L= Horn Length, TL=Tail Length, DL=Dewlap Length, SC=Scrotal Circumference, UC=Udder Circumference, No. T= Number of Teats, $\mathrm{F}$ LL=Forelimb Length, H LL=Hind limp Length, C.CF=Cannon Circumference, $\mathrm{HC}=$ Horn circumference, $\mathrm{CL}=$ Cannon Length, $\mathrm{RW}=$ Rump Width, RL=Rump Length, $\mathrm{HG}=$ Heart Girth. 
other traits. Cannon length (CL) correlated rp negative with all the phenotypic traits except scrotal circumference (SC), udder circumference (UC) and body weight (BW). Those phenotypic traits that are negatively correlated means that improvement in one trait may lead to decrease in the other traits [19].

\section{Conclusion}

Based on this study age and lots had effect on phenotypic traits of cattle in Obudu cattle ranch. Body weight showed positive correlation with all phenotypic traits, while cannon length showed negative correlation with the entire phenotypic trait except UC, SC and BW. The positive correlation among phenotypic traits could be used for improvement because improvement in one will lead to improvement in others. The study will be useful in planning for selection and breeding programmes of cattle.

\section{References}

1. Yakubu A, Idahor KO, Haruna HS, et al. Multivariate analysis of phenotypic differentiation in Bunaji and Sokoto Gudali cattle. Acta Agriculturae Slovenica. 2010;96(2):75-80.

2. Abanikannda OTF, Leigh AO, Olutogun O. Linear measurements-based discriminant classification of Zebu cattle in Lagos State. In: Fanimo AO and Olanite JA (eds.). Contributory role of animal production in national development. Proceedings of the $7^{\text {th }}$ Annual Conference of Animal Science Association of Nigeria, held at the University of Agriculture, Abeokuta, Nigeria. 2002;pp:355-56.

3. Banerjee S. Morphometrical and production traits of Bengal sheep in West Bengal, India. Anim Genet Resour. 2015;57:57-71.

4. Boettcher PJ, Ajmone MP, Lenstra JA. Recent developments in the genetic characterization of animal genetic resources. $8^{\text {th }}$ World Congress on Genetics Applied to Livestock Production, Leipzig, Germany. 2010;pp:1-6.

5. FAO. Coping with climate change: The roles of genetic resources for food and agriculture. Rome, Italy. 2015.

6. FAO. Phenotypic characterization of animal genetic resources. FAO Animal Production and Health Guidelines No. 11. Rome, Italy. 2012.

7. FAO. Draft guidelines on phenotypic characterization of animal genetic resources. In: Proceeding of Commission of Genetic Resources for Food and Agriculture. Rome, Italy. 2011;pp:85-8.

8. Ekweume B. Precambrian geology and evolution of the South Eastern Nigeria basement complex. Calabar: University of Calabar Press, Nigeria, Africa. 2000.

9. Mabugunje A. Nigeria: Physical and social geography in Africa, South of the Sahara, (12 ${ }^{\text {th }}$ edn). 1983;pp:760-70.

10. Adejoro FA, Salako AE. Morphobiometric characterization of the Balami sheep of Nigeria. Afr J Gen Agric. 2012;8(4):169-73.

11. Dauda A, Abbaya HY, Shettima SM, et al. Phenotypic differentiation of Koroji sheep in Maiduguri. Niger J Anim Sci. 2018;20(2):33-41.
12. Brown DE, Maher CR, Mitchell CD. A comparison of Pronghorn body measurements throughout Western North America, Proceedings of the 22nd Biennial Pronghorn Workshop, USA. 2006;pp:125-37.

13. Vargas S, Larbi A, anchez M. Analysis of size and conformation of native Creole goat breeds and crossbreds used in smallholder agrosilvopastoral systems in Puebla, Mexico. Trop Anim Health Prod. 2007;39:279-86.

14. Rege JEO. Te state of African cattle genetic resources I. Classifcation framework and identifcation of threatened and extinct breeds. FAO/UNEP Animal Genetic Resources Information Bulletin. 1999;26:1-26.

15. Espinoza JL, Guevara JA, Palacios A. Morphometric and phaneroptic characterization of Mexican Criollo Chinampo cattle. Archivor Zootechnic. 2009;58:277-79.

16. Alsiddig MA, Babiker SA, Galal MY, et al. Phenotypic characterization of Sudan Zebu cattle (Baggara type). Res J Ani Vet Sci. 2010;5:10-7.

17. Al-Amin M, Nahar A, Bhuiyan AKFH, et al. On-farm characterization and present status of North Bengal Grey (NBG) cattle in Bangladesh. Animal Genetic Resources. 2007;40:55-64.

18. Martins CEN, Quadros SAF, Trindade JPP, et al. Shape and function in Braford cows: Te body shape as an indicative of performance and temperament. Archivor Zootechnic. 2009;58:425-33.

19. DaudaA, Okon B, Ibom LA, et al. Phenotypic characterization of Balami breed of sheep in Maiduguri, North-Easthern Nigeria. Niger J Anim Sci. 2018;20(2):26-32.

\section{*Correspondence to:}

Dauda A

Department of Animal Science, University of Calabar, Nigeria

Tel: +2347036707201

E-mail: ayubadauda87@gmail.com 